ASLI QoL 2017
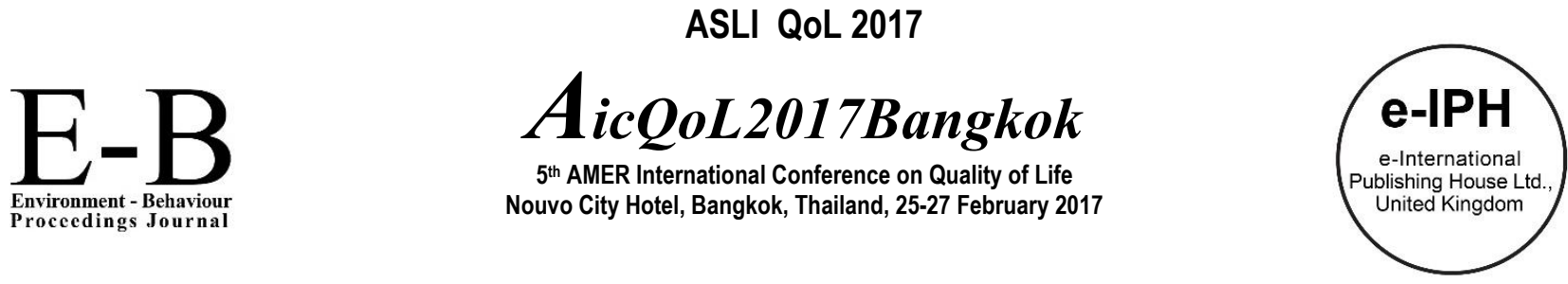

\title{
Reviving the Lost Place Identity of Batu Pahat, Johor
}

\author{
Wan Hashimah Wan Ismail1*, Nurul Atiqah Che Noh \\ 1 Department of Architecture, Faculty of Built Environment, Universiti Teknologi Malaysia, Malaysia
}

\begin{abstract}
In the past, Batu Pahat was well known as a textile center to the locals and visitors. The paper aims to discuss the place identity of Batu Pahat, the factors that contribute to the loss of the identity and the possible ways in reviving the place identity. The research was conducted through the reading of past documents and records, observation, and interview of the locals. Several factors contributed to the loss of place identity. Possible solutions in reviving the place identity were to upgrade the waterfront, revitalize the old buildings, and to include a textile center.
\end{abstract}

Keywords: place identity; textile; shop

ISSN: 2398-4287@ 2017. The Authors. Published for AMER ABRA by e-International Publishing House, Ltd., UK. This is an open access article under the CC BYNC-ND license (http://creativecommons.org/licenses/by-nc-nd/4.0/). Peer-review under responsibility of AMER (Association of Malaysian Environment-Behaviour Researchers), ABRA (Association of Behavioural Researchers on Asians) and cE-Bs (Centre for Environment-Behaviour Studies), Faculty of Architecture, Planning \& Surveying, Universiti Teknologi MARA, Malaysia.

\subsection{Introduction}

In the 1990s, Batu Pahat was well known as a textile center to the locals and visitors. Many of the shophouses were engaged in selling textiles produced locally by several factories, about 10 kilometers from the riverside. 'Batu Pahat-Textile Town' identity was well known throughout Batu Pahat and also to the other states in Malaysia. Many people flocked to the area to get quality textiles, especially close to festival seasons.

The paper aims to discuss the textile identity of Batu Pahat, the factors that contribute to the loss of textile identity and the possible ways in reviving the identity for the benefit of the contemporary as well as future generations.

Thus, the objectives to be achieved in this study were to investigate the textile identity in Batu Pahat, to identify the factors that contributed to the loss of the identity and to seek for possible programs or projects that could revive the past glory. Therefore, the scope of this study was limited and focused on the textile identity of Batu Pahat only.

\subsection{Methodology}

The urban study of Batu Pahat was conducted by 9 Master of Architecture students from the urban unit of Architecture Department, Universiti Teknologi Malaysia. Several methods were employed to get the necessary information for the research. The data was collected through the reading of past documents or records, observation, and interview of the local authority and the locals.

The review of the literature was done by referring to the printed sources such as books and articles, data from the local authority and internet sources. The necessary information includes the history of Batu Pahat with specific reference to textiles. The other important information required was the history of textile industry and the area where the activities of selling and buying of textiles took place. Written questionnaire was distributed to the local to find out their perceptions of the town. The outcome was further supported by a semi-structured interview conducted to probe focusing on the industry, shopping, and selling of textiles in Batu Pahat.

There were two main segments of the observation. The first was to get an overall picture of the town. The information necessary includes the current siting of the textile factories and to locate the shops or area where textiles were sold. The other aspect was to

\footnotetext{
* Corresponding author. Tel.: +6-016-765-1378

E-mail address: wan7137shima@gmail.com
}

ISSN: 2398-4287@ 2017. The Authors. Published for AMER ABRA by e-International Publishing House, Ltd., UK. This is an open access article under the CC BYNC-ND license (http://creativecommons.org/licenses/by-nc-nd/4.0/). Peer-review under responsibility of AMER (Association of Malaysian Environment-Behaviour Researchers), ABRA (Association of Behavioural Researchers on Asians) and cE-Bs (Centre for Environment-Behaviour Studies), Faculty of Architecture, Planning \& Surveying, Universiti Teknologi MARA, Malaysia. 
observe the human activities in relation to the selling and buying of textiles. All the related information focusing on textile identity was then analyzed. Only then the conclusion was drawn.

\subsection{Literature review}

\subsection{History of Batu Pahat}

Batu Pahat town acquired its name that means "chiseled stone" from the past history (Fig. 1a). It was derived from the chiseling of rocks to get fresh water by the Siamese troops, led by Admiral Awi Di Chu around 1456. The army camped in the coastal village of Kampung Minyak Beku, not far from the present Batu Pahat town. Their mission was to attack Malacca Empire but lost in their course.

The present Batu Pahat town was founded by Dato' Muhamad Salleh bin Perang in 1893, acting on the order of Sultan Abu Bakar, the king of Johor. The position of the new town was 15 kilometers from the estuary, where the Batu Pahat River meets the Straits of Malacca (Fig. 1b). The place was chosen because it was considered suitable for the anchorage of ships for the ease of sea trading. The place was often flooded but there was fertile land on a higher ground, 2 kilometers further inland. The founder built his house at Kampung Penggaram, opposite to Kadri Lake to supervise the opening of the town. The town was formerly known as Bandar Penggaram that means "town of salt-makers".

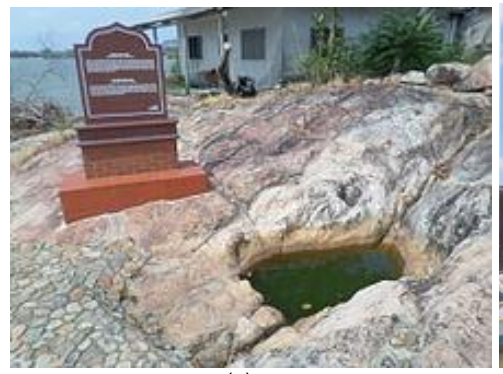

(a)

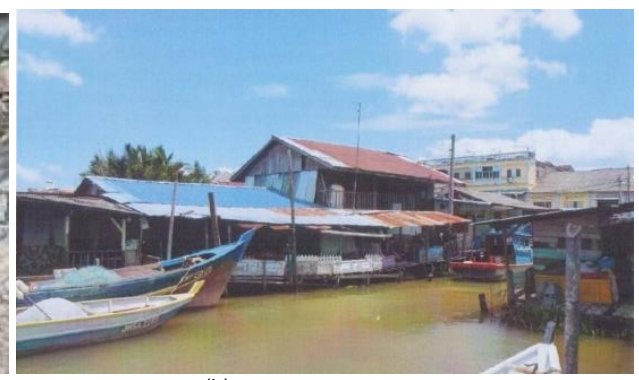

(b)

Fig. 1. (a) Chiseled stone; (b) Batu Pahat riverside.

Batu Pahat owes its development partly to the growth of small and medium industries such as textiles, garments, and electronics. Batu Pahat was upgraded to town status (Majlis Perbandaran) in 2001, alongside Muar, Kluang, and Skudai. The town grew rapidly and is now considered as the second major town in Johor state after Johor Bahru (Fig. 2a and Fig. 2b).

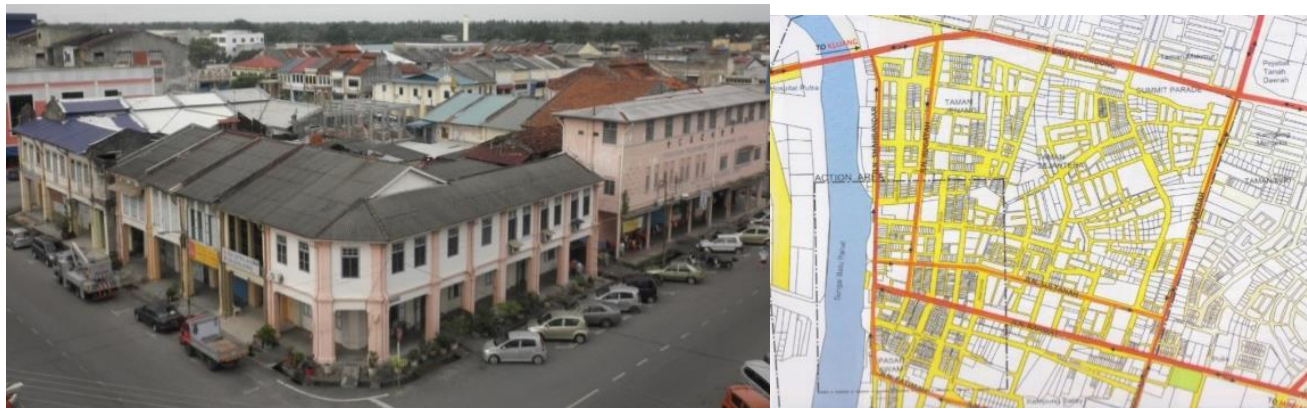

(a)

(b)

Fig. 2. (a) Batu Pahat town; (b) Map of Batu Pahat.

\subsection{Textile trading}

Textile is a material made by weaving, knitting, crocheting, felting or interlacing fibers either natural or synthetic. Textile can also know as fabric and clothes. The different is, fabric is referred to any materials that may be used in a production of further goods like garments and clothes through several processes like weaving, knitting, spreading, crocheting or bonding (Wikipedia, 2016). Textile can be produced using two types of fiber, either natural or synthetic. There are three types of natural-based fibers, animal-based like wool and silk, plant-based like linen, cotton and pineapple leaves and also mineral-based like asbestos and glass fiber. Materials like polyester and rayon are the examples of synthetic and non-natural materials.

The record of Maritime trade with Indian textiles to South-East Asia goes back as early as the fifth century CE in a Chinese document. It refers to the carrying of textiles from India on an Indonesian diplomatic mission to China. Both cotton for textile purposes and the knowledge of extracting the dye was known to have originated from India. Javanese tax records of the early tenth century already mention textiles of many colors (Barnes, 1997). Thus, the textile was considered worthy to be included as part of the items for trading and taxable. According to SP Sen (1962), it was the Indian merchants who introduced the importance of Indian textile in building up a profitable trade with Southeast Asia to the Portuguese, the Dutch and the English 
On the mainland, the trading of textile could be traced back to Silk Road or Silk Route, consisting of a series of ancient routes that connect East and West. The routes linked traders, merchants, pilgrims, monks, soldiers and urban dwellers from China to the Mediterranean Sea. Trading across the continents had already existed before this trade route was initiated by the Han Dynasty around $114 \mathrm{BC}$. The route connected Chang'an (today Xi'an) in China, with Asia Minor and the Mediterranean. The route extended over $8,000 \mathrm{~km}$ on land and sea. Trading along the Silk Route was an important factor for the development of several civilizations, such as at China, Egypt, Mesopotamia, Persia, the Indian subcontinent, and Rome. It also formed the foundations for the modern world (Wikipedia, 2016).

\subsection{Place identity}

The identity of a person or place is the qualities or beliefs that make a particular person or place different from others. The person or place can be recognized by having a unique identity or a particular character and people can identify if some changes happen to that person or place. Scholars relate place identity to the meaning and significance of places for their inhabitants and users. Relph (1976 in Mohd Riduan, 2016) notes that place identity could best be understood as that which makes a place unique. The important aspects are the identity of a place and the identity that a person or group has with that place. Thus, it relates to the meaning and significance of places for their inhabitants and users and the effect on the individuals' conceptualizations of self.

Proshansky et. al (1983 in Mohd Riduan, 2016), defined place-identity as a mixture of conceptions, interpretations, ideas, memories, conceptions, interpretations, ideas, and related feelings about specific physical settings, as well as types of settings. The area of concern includes geography, environmental psychology, urban planning, urban design, landscape architecture, and urban sociology or ecological sociology. On the whole, it can also be referred to as the urban character, local character or neighborhood character.

Relph (1976 in Carmona, 2003) relates that even though the meanings of places are rooted in their physical setting and activities, but it relies on human intentions and experiences. Thus, what the 'environment' represents is a function of our own subjective construction of it. Thus, the humans are the ones who shape the environment and give meanings to it.

One of the aspects that form place identity is continuity. According to Twigger-Ross \& Uzzel (1996 in Nurlisa \& Julaihi, 2015), a continuance existence can help to reshape and maintain the identity of a place. The presence of an older building, for instance, can help us to remember or turn back a memory (Lalli, 1992). Continuity can be defined in two forms, place-referent continuity, and placecongruent continuity. Place-referent continuity means a particular place that is capable of producing continuity aspects in physical forms that may remind visitors of the past. Place-congruent continuity concerns the attributes chosen by each person in relation to a place. Some people choose a place because of the ideas, lifestyle, and values rather than its physical form (Twigger-Ross and Uzzell, 1996). Those values are customs, a principle of life, religion, habit or others. The stability of these values enables the people to evoke memories without being affected by the physical changes of the surroundings.

In the research conducted by Nurlisa \& Julaihi (2015), it was found that there were three aspects highlighted by the visitors concerning the identity of the place. The strongest was the values while familiarity and nostalgia have a low effect on the visitors. However, it was also found that the continuity aspect of the research area does not have a large role in forming the place identity.

As noted by Norsidah (2009) place identity is linked to meanings and perceptions held by the people in relation to their environment. The significant components of the place identity highlighted in the research were the physical elements, activity, and image. The attributes associated with physical element were accessibility and legibility. For the activity, the attributes include vitality, diversity or choice and transaction. The attributes related to an image are legibility, distinctiveness, comfort, and safety or security. Thus, even though the physical elements, especially the buildings, play a major role in forming the place identity, the other aspects, particularly the activities and image are also important.

The study of place identity is considered vital since urban regeneration may transform places and constructed meanings embedded in the social and culture within the traditional settings (Norsidah and Khalilah, 2015). The social and emotional meanings, attached to or evoked by the elements of the existing urban environment were important since it relates to the imagery of the individuals. The meanings were the psychological dimension of the inhabitants towards their urban setting. Place-based approach and principles in the era of urban regeneration and its implication are important on the continuity of place meaning and identity in the Asian context.

Norsidah and Khalilah (2015) posit that a change and transformation of buildings and spaces may result in a loss of identity. The modernist approach in changing the uses and function of old buildings to relate to contemporary issues may contribute to a deterioration of historical cities (Salama, 2009). New developments within the traditional settings in the city center transform places together with the place meanings and attachment embedded in the existing cultural and social setting (Norsidah, 2009). The loss of identity weakens the attachment, depth of meaning, and diversity of place experience. These arguments dictate the importance of sustaining the meanings and identity of the urban elements and icons as they contribute to sense of community, self-identity, and sense of place (Hull et al., 1994).

An effort to retrieve a place identity was exemplified by Helga (2016). Her study was aimed at enhancing the natural landscape of a small urban area, principally dedicated to tourism, through the recovery of the traditional manner of olive cultivation which is at risk of extinction. The main aim was to recuperate ancient, abandoned olive groves and convert them to organic cultivation in order to produce very high-quality olive oil. Olive was important as one of the primary elements of the Mediterranean diet launched as a global dietary model by recent UNESCO heritage policies (Moro, 2014). The other aspect concerns the symbolic origins of extra-virgin olive oil that are rooted in Greek mythology. According to the legend, a fruit-bearing olive tree was given to man by the goddess Athena (Helga, 2016). The study gave an example of intangible cultural heritage to a place. 


\subsection{Findings and Discussions}

\subsection{Textile identity}

From literature review and interview of the locals, it was found that Batu Pahat had a large number of textile and garment factories that produced high-quality textiles, fabrics, clothes and various garments. The factories produced textiles not only within Malaysia but also exported to other countries and successfully penetrated the international business marketing.

From the interview of the locals, it was found that the knowledge of the textile identity of Batu Pahat defers according to the age groups. It was found from the interview that textile identity was only known to the old folks of Batu Pahat. The young adults could recall some experiences shopping textiles at the riverfront of Batu Pahat. However, the younger locals or visitors to the area had no knowledge of the textile identity of the town

In the past (the 1990s), the primary area for the selling of textiles in Batu Pahat was in the area close to the riverfront of Batu Pahat. The main components of the area were the rows of the old shophouses that formed the early built structures of the place. In the past, the shopping streets for selling textiles were those close to the bus terminal. The popular textile streets were Penggaram Street, Soga Street, and Rugayah Street. The bus terminal was the transit point for people to move in and out of the town since not many people owned cars in the past. The easy connectivity by using the buses enabled the locals and the visitors to shop within the area. Furthermore, the market, another popular destination was not far from the bus station. In the past, there were a lot of trishaws that could give the shoppers a ride to any destinations around the area.

The industries relating to textiles together with garments and electronics helped to boost the development of Batu Pahat. It was through these small and medium industries that Batu Pahat was upgraded to town status (Majis Perbandaran) in 2001, alongside the other main towns in Johor, namely Muar, Kluang and Skudai (Wikipedia, 2016).

It was noted earlier that place identity is related to the meaning and significance of places for their inhabitants and users (Relph,1976 in Mohd Riduan, 2016). In the case of Batu Pahat, what made it significant in the past were partly the textiles. The trading of the textiles was one of the factors that made the place unique and significance to the inhabitants and other users. This aspect relates to what was noted by Norsidah (2009) whereby place identity is linked to meanings and perceptions held by the people in relation to their environment. One of the significant components of the place identity was the activity. In this case, the activities concerned were the selling and buying of textiles in Batu Pahat. From the interview, those who remembered the textile activities were not really concern on the setting of the activities. They were more concern on the merchandise, rather than the shophouses that housed the activities.

\subsection{Textile trading at present}

Currently, there are 19 textile factories operating in producing textiles both textile and clothing around Batu Pahat. However, the riverside old town has lost its identity as the 'Textile Town'. Through the observation studies of the area, it was found that there were very few textile shops still operating. There were only 3 textile shops along Soga Street, close to the bus terminal (Fig.3a).

The majority of the locals interviewed stated that they rarely do shopping textile and clothes at Soga Street and preferred to go to the shopping complexes such as Batu Pahat Mall, Square One Shopping Mall and Aeon Big (Table 1). These new malls are located at Persiaran Flora Utama Street, and along Kluang Road, away from the old town center, the location of the textile center in the past. The study on the viscosity of the visitors around the old town showed that the busiest places were the market, followed by the bus terminal in the morning. At night, the busy places were the eatery by the riverside and the bus terminal. The other places or shops, including the textile shops in the old town, were very quiet.

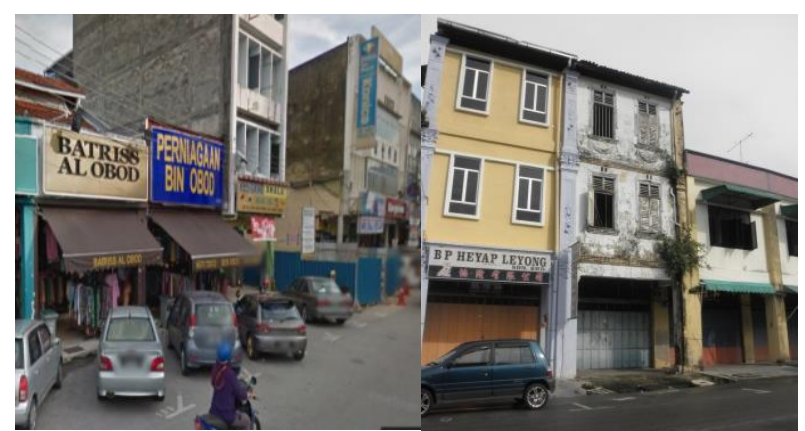

(a)

(b)

Fig. 3. (a) 3 textile shops along Soga Street; (b) Shophouses in dilapidated state.

Table 1. Preferred Places of the locals

\begin{tabular}{|l|c|}
\hline Preferred Places of the locals & Percentage \\
\hline Shopping mall & $42 \%$ \\
\hline Café/hawker & $42 \%$ \\
\hline Park/Beach & $16 \%$ \\
\hline Total & $100 \%$ \\
\hline
\end{tabular}

(Source: Author) 


\subsection{Factors contributing to the loss of the place identity}

There were many factors that contributed to the loss of textile identity through time. First and foremost is the development of Batu Pahat town. The town has grown further inland over the years, away from the riverside. Several modern shopping complexes were built further away, about 3 kilometers from the riverfront. The intention was to avoid the congestion at the town center. Thus, many new shops and shopping complexes were built within the new town along Kluang Road. The move somehow shifted shoppers away from the riverside area. The advantages of the new town were the shopping malls and textile store shops were built next to one another. A centralized commercial area creates feeling of ease to the shoppers as they could drop and park their vehicles at one place and then walk from one mall to other shops to buy their needs.

It was observed that many of the old shophouses close to the riverside were in a dilapidated state (Fig. 3b). This situation includes the shophouses that once housed the trading of textiles in the past. Only a few of the shops were still operating while many of them seem to be permanently closed. The shopkeepers of a shophouse facing the river selling salted fish, for instance, used the ground floor only. The upper floor was not maintained and considered unsafe.

The trading of textiles had also changed over the years. Through the interview of the operators of the textile shops in Batu Pahat, it was found that the shops did not rely on local products only. Some of the textiles were imported from China and Japan. It was also common for the shops to get their supplies from textile suppliers rather than to buy directly from the local factories.

As mentioned earlier, through viscosity study of the area it was found that the highest density of visitors was around the bus terminal and the market. It was also noticed that the majority of the visitors to the market that was close to the riverside were adults. There were rarely youths hanging out within the area. The finding showed the lack of excitement within the area for the younger generation. From the observation and interview with the local people, there were a few favorite spots of a public area for gathering and recreation. The places mentioned were Dataran Pahlawan, Batu Pahat Walk, Taman Rekreasi Tasik Y and at eatery places. However, all these places were not really favorable for the whole day as some of the places face heavy traffic and also noisy. The other constraints were the hot weather and less shaded area. All these negative aspects make it preferable for the visitors to spend time with family and friends in indoor places, such as the shopping malls.

It was noted earlier that one of the aspects that form place identity is continuity (Twigger-Ross \& Uzzel, 1996 in Nurlisa \& Julaihi, 2015). A continuance existence can maintain the identity of a place. It was mentioned that the presence of an older building, for instance, can help us to remember or turn back a memory (Lalli, 1992). However, in the case of the old town of Batu Pahat, the aspect of continuity seems to be not practical. In the case, place-referent continuity, many of the old shophouses associated with the selling and buying of the textiles within the area were already in a dilapidated state. An upgrading of the area by maintaining the old shophouses would be rather costly. The past activities that relate to the active selling and buying of textiles had reduced a great deal over the years. Thus, place-congruent continuity has greatly minimized and there is a difficulty in bringing back its past glory.

\subsection{Conclusion}

The old town of Batu Pahat has the distinctiveness that differs it from the others. The unique qualities of the area relate to the past activities in relation to the selling and buying of textiles. The quality was well known throughout Batu Pahat and also to the other states in Malaysia. However, in this case, the aspect of continuity seems to be not practical. The current condition of the surrounding buildings and the shifting of the favorable shopping area may hinder an effort to revive the past glory of the place. Thus, alternative solutions can be injected to revive the identity of the place. A possible solution is to upgrade both the riverside and the surrounding buildings. The riverside could be a pleasant extension of the market, a popular hotspot for the locals. The old buildings could be revived and could be used again in activities relating to textiles. Craft relating to textiles, for instance, could be introduced to bring interest to the young and old. This effort should include activities that relate to the culture of the locals. The past place identity could be made known to the public by creating a new one-stop textile shop or hub. This place can become a center to learn about textile, to find or buy all kind of textiles, fabric or clothes. It could include other services such as networking that connect local and international textile industry. The center could bring back the lost place identity of Batu Pahat, relating to the activities dealing with textiles. Researchers recommend for further research on how to improve the situation.

\section{Acknowledgements}

This study was made possible by the continuous support from Universiti Teknologi Malaysia

\section{References}

Barnes R. (1997) Indian Block-Printed Textiles in Egypt: The Newberry Collection in the Ashmolean Museum, Oxford.

Bernardo F. \& Palma-Oliveira J.M. (2016). Urban Neighbourhoods and Intergroup Relations: The Importance of Place Identity. Journal of Environmental Psychology, 45, 239-251.

Majlis Perbandaran Batu Pahat (2016). Study on the Auditing and Improvement of Tourism Products and Package Tours in Johor.

Mohd Riduan N., Hafazah A. K. \& Syed Sobri Z. (2015). Image of Urban Public Park during Nighttime in Relation to Place Identity. Procedia - Social and Behavioral Sciences, 170, 452-462. 
Wan Ismail, W.H., \& Che Noh, N.A. / $5^{\text {th }}$ AicQoL2017Bangkok, 25-27 February 2017 / E-BPJ, 2(5), March 2017 (p. 479-484)

Norsidah Ujang (2012). Place Attachment and Continuity of Urban Place Identity. Procedia - Social and Behavioral Sciences, 49, $156-167$.

Norsidah U. \& Khalilah Z. (2015). The Notion of Place, Place Meaning and Identity in Urban Regeneration. Procedia - Social and Behavioral Sciences, $170,709-717$.

Nurlisa G. \& Julaihi W. (2015). Exploring Identity's Aspect of Continuity of Urban Heritage Tourism. Procedia - Social and Behavioral Sciences, $202,234-241$. 